\title{
Démonétisation et tyrannie dans Edouard II
}

\section{Ann Lecercle}

\section{(2) OpenEdition \\ Journals}

\section{Édition électronique}

URL : http://journals.openedition.org/shakespeare/1263

DOI : 10.4000/shakespeare.1263

ISSN : 2271-6424

Éditeur

Société Française Shakespeare

Édition imprimée

Date de publication : 1 novembre 1993

Pagination : 149-160

Référence électronique

Ann Lecercle, "Démonétisation et tyrannie dans Edouard |/ 》, Actes des congrès de la Société française Shakespeare [En ligne], 11 | 1993, mis en ligne le 01 janvier 2007, consulté le 27 avril 2019. URL : http:// journals.openedition.org/shakespeare/1263; DOI : 10.4000/shakespeare.1263

Ce document a été généré automatiquement le 27 avril 2019

(C) SFS 


\section{Démonétisation et tyrannie dans Edouard II}

Ann Lecercle 